\title{
MAINTENANCE STRATEGY FOR VEHICLE WITH ELECTRONIC FUEL INJECTION SYSTEM
}

\section{STRATEGIA OBSEUGIWANIA POJAZDU Z ELEKTRONICZNYM SYSTEMEM WTRYSKU PALIWA}

\author{
Carla Mericia Monteiro Tavares, Janusz Szpytko
}

AGH University of Science and Technology, Krakow, Poland Akademia Górniczo - Hutnicza im. St. Staszica w Krakowie

\begin{abstract}
The introduction of new vehicles technology has been projected for advanced technologically places. Their use and operation, is a theme of big concern for developing countries. This work is part of the study for the creation and establishment of a maintenance strategy and policy, which will be acceptable in developing countries. The paper proposes a methodology for the identification of critical components of the electronic fuel injection system with failure mode, effects and criticality analysis tool (FMECA). With the elaboration of this work, was possible to visualize that the maintenance strategy for each component depends strongly on the availability of equipment for the diagnosis (fail detection). As future work, would be important to study the influence of others parameters that influence the maintenance and vehicle operation, as cost, environment, human aspect and vehicle operation. Another useful analyses would be, to analyses the data in a probabilistic interpretation in order to visualize influence of each component failure in the system failure.
\end{abstract}

Keywords: maintenance strategy, fuel injection system, developing countrie, FMECA

Streszczenie: Celem pracy jest budowa założen do strategii procesu obshugiwania silników spalinowych $z$ wtryskiem elektronicznym akceptowana $w$ krajach rozwijajacych się. $W$ artykule przedstawiono metodologie identyfikacji istotnych elementów elektronicznego systemu wtrysku paliwa $z$ wykorzystaniem analizy krytyczności typu FMECA. W rezultacie własnych badań stwierdzono, że realizowana strategia obshugiwania przedmiotowych silników $w$ dużym stopniu zależy od dostẹpności aparatury diagnostycznej umożliwiajacej identyfikację źródta obserwowanego niekorzystnego zdarzenia. Podjęto prace ukierunkowane na badanie wphywu na proces obstugiwania silników spalinowych z wtryskiem elektronicznym: procesu użytkowania, wiedzy technicznej ich użytkowników, środowiska eksploatacji, kosztów eksploatacji. W tym celu opracowano mechanizm pozyskiwania i prezentacji danych od użytkowników pojazdów z silnikami spalinowymi zwtryskiem elektronicznym.

Stowa kluczowe: proces obstugiwania, uktad wtryskiwania paliwa, analizy krytyczności, FMECA 
Maintenance strategy for vehicle with electronic fuel injection system

Strategia obstugiwania pojazdu z elektronicznym systemem wtrysku paliwa

\section{Introduction}

The introduction of new vehicles technology has been projected for advanced technologically places. Their use and operation, is a theme of big concern for developing countries [1]. Previous study made by the authors was focusing on the study of problems related to the operation of new vehicles, especially vehicles maintenance assistance, taking under consideration, human feature and skills, and operational environmental. Five developing countries has been taken as case study (Cape Verde, Cuba, Colombia, Costa Rica and Zimbabwe), countries with different culture, people, background and geographic localization. As a result of the study was possible to identify similar problem related to vehicle operation and maintenance in different countries, the main source for the existing problem is related to the existing infrastructure, lack of technical support and human aspect [2].

Due to the need to improve vehicle fuel economy for the propose of preventing global warming and reducing exhaust gas emissions that affect human health, diesel engine vehicles are highly acclaimed in Europe, due to the good fuel economy that diesel fuel offers. Diesel vehicles are manufactured according to the following demands: Reduce exhaust gases (e.g.: NOx, PM, carbon monoxide (CO), hydrocarbon (HC) and smoke), improve fuel economy, reduce noise, improve power output and driving performance. The fuel injection system (including the injection pump and nozzles) plays a significant role because it directly affects the performance of the engine and the vehicle [3]. The design of the fuel injection system are developed according to the acquired knowledge, information, analysis and working condition in developed countries. There is a need for the study of the reliability in the operation, and maintenance of this vehicles, in countries with low level of grow, and technology capabilities [4] (developing countries).

High value products as emerging technology vehicles, are technology intensive and reliability critical, requiring continuous maintenance throughout their life cycle. The adaptation of these new technologies for maintenance support is not an easy passage, as it implies a considerable cultural change in management in general, and maintenance in particular. A research in order to have knowledge, and understand the influence of the human feature and skills, and operational environmental on the vehicle operation and maintenance is needed. It is necessary to design a solution that can allow to move with safety and ensure an reliable operation of vehicles. The lack of proper maintenance in vehicles has caused major accident, which shows that a proper maintenance on vehicles is a subject of a major importance, a proper maintenance procedure makes a big difference [1].

With the elaboration of this work is intended to support the creation of a maintenance strategy and policy which will be acceptable to the specific conditions: human practice and knowledge, technical environmental, operational environmental, and access to new elements for change under service process. The maintenance strategy should be created including the needs as reliability, safety and cost. 
For this a reliability assessment in the engine system will is proposed, considering working condition in a developing country, through the application of reliability method, failure models, effects, and criticality analysis (FMECA).

The objective of this work is to support the identification and management of critical components of a vehicle as well as the best maintenance strategy. In the case of study, the uncertainty analysis is done according to data provided by maintenance experts, some values are assumed based on system failures.

\section{Theoretical reference: maintenance and reliability}

The purpose of maintenance activity is to obtain a certain degree of continuity in the productive process, this objective, in the past, was pursued through operational and functional redundancies, by guaranteeing a calculated excess of productive capacity or, finally by applying an aggressive programme of revision and replacement of critical systems [5]. The ultimate goal of maintenance is to provide optimal reliability that meets the business needs of the company, where reliability is defined as the probability or duration of failure-free performance under stated conditions [6].

Advanced maintenance today is related to data processing and communications technologies. maintenance has been transformed, in terms of its mission, from a prevalently operational activity of repair to a complex management system, oriented more than anything else towards the prevention of failures. This is not an easy passage, as it implies a considerable cultural change in management in general and maintenance in particular.

From a basic point of view there are two maintenance approaches. One approach is reactive and the other is proactive. In practice there are many combinations of the basic approaches. The reactive system responds to a work request or identified need, and depends on rapid response measures if effective. The goals of this approach are to reduce response time to a minimum (the computer helps) and to reduce equipment down time to an acceptable level. This is the approach used by most operations today. The proactive approach, responds primarily to equipment assessment and predictive procedures. The goals of this method are continuous equipment performance to established specifications, maintenance of productive capacity, and continuous improvement [7].

The maintenance management concept was developed with the idea that maintenance would be planned and managed in a way that provides an efficient continuous operating facility at all times. Maintenance would also be treated as an investment rather than a cost.

Basing in the maintenance culture practiced in developing countries, for this work it is proposed the following tree types of maintenance strategy. Breakdown maintenance (systems easy to replace at low cost), it is convenient to wait for the failure to occur before intervening. 
Maintenance strategy for vehicle with electronic fuel injection system Strategia obstugiwania pojazdu z elektronicznym systemem wtrysku paliwa

It is therefore necessary to identify the component that has broken down and take all the measures necessary to re-establish the operational integrity of the system.

Preventive maintenance (define in advance the time of intervention), generally consisting in replacement, as a function of the expected life cycle of the component. Predictive maintenance is known as the more modern vision of maintenance problems, uses non-destructive techniques to test systems in order to identify the presence of failures, and programme a revision only when the condition of the machine determined the need [5].

As mentioned before, reliability is the ability of an item to perform a required function under a stated set of conditions for a stated period of time. However, many companies focus on fixing equipment when it has already failed rather than ensuring reliability and avoiding failure [6]. As the case of developing countries, this practice is due to lack of knowledge and information, lack of technical equipment's and people behavior (this is the way we have always done it). This practice can decrease the reliability of the equipment, those the correct maintenance strategy is very important. The lack of proper maintenance brings many negative consequences for the equipment as higher maintenance cost, increased equipment failure and availability problems.

To improve the reliability of the system, it is important the use of statistical analysis. This work propose the reliability analysis, through the monitoring the health of selected components. The reliability analysis will be done through the use of the reliability method, failure models, effects, and criticality analysis (FMECA). In most of the developing countries, maintenance is known as fix, restore, replace, recondition, rebuild, and rejuvenate, there is lack of maintenance culture or policy, the definition of maintenance remain unknown. With this work is intended to support the creation and establishment of a maintenance strategy, and policy, which will be acceptable to the specific conditions: human practice and knowledge, technical environmental, operational environmental, and access to new elements for changes under service process. In order to support the identification of the maintenance strategy, will be applied a math - based reliability model, Failure models, effects, and criticality analysis (FMECA).

FMECA (Failure Models Effects, and Criticality Analysis), is a quantitative method used to classify the modes and effects of critical failures taking into account their probability of occurrence. Is a technique that helps to identify and prioritize potential failures in equipment, systems or processes, and provides recommendations for actions that aim to avoid them through maintenance techniques [6]. According to the authors, the failures found through the FMECA technique are prioritized based on the criticality of the causes, using the RPN (Risk Priority number) index, composed of the following indicators: severity, occurrence (frequency Fault mode occurs) and detection (degree of ease to detect fault) [8]. 


\section{Proposed Methodology}

For this work will be used as a case of study, maintenance of a vehicle equipped with electronic fuel injection system (common rail type). The common rail system use a rail (accumulation chamber) to store pressurized fuel, and injectors to inject the pressurized fuel into the cylinder. The injection system is controlled by the ECU. The common rail control system can be divided in: sensors, engine, ECU (Electronic control unit), EDU (electronic driving unit), and actuators. All components of the system is shown in the Figure 1 [5].
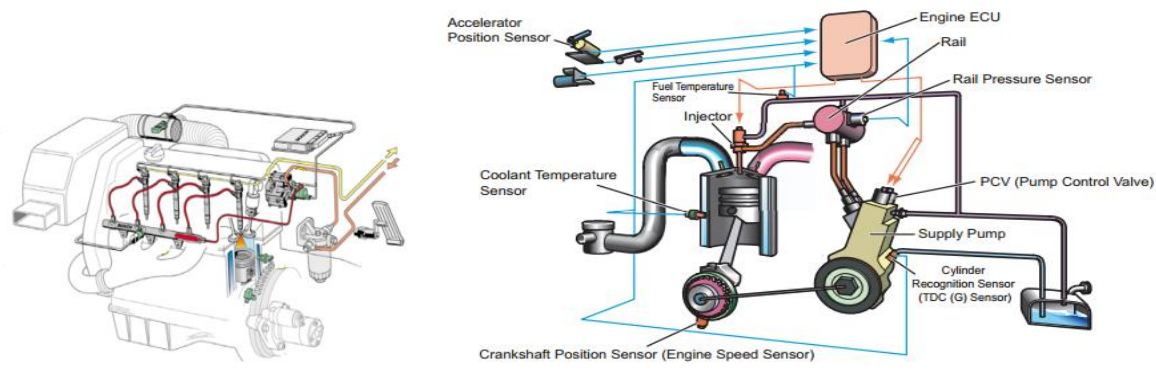

Fig. 1 Configuration of main components of the common rail system [5].

For the analysis and identification of the critical components of the system, this work propose the use of the framework bellow (Figure 2). In order to collect data for the measurement of values. Considering that a certain malfunction is identified (Damage exposure _DEX), It is necessary to identity the System in which the damage is related to, the components affected, and their causes. After the identification of the damaged components scenarios, it is necessary to assign probabilities.

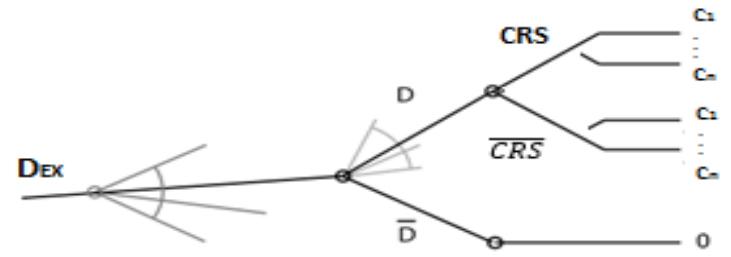

Fig. 2 Proposed event tree for analyse and identification of the critical components

First an exposure is identified, this has potential of damaging components in the system $\left(D_{\mathrm{EX}}\right)$. If no damage in the system components occurs $(\overline{\mathrm{D}})$, the analysis is finished. If damage occurs (D), this damage is related to the Common rail system (CRS) of the vehicle, or other than CRS $(\overline{\mathrm{C}} \overline{\mathrm{R}} \overline{\mathrm{S}})$, the malfunction can be related to many faulty item as the intake system, Fuel system, engine or others. The malfunction is related to some specific competes of the system $(\mathrm{C} 1, \mathrm{C} 2, \ldots, \mathrm{Cn})$. 
Maintenance strategy for vehicle with electronic fuel injection system Strategia obstugiwania pojazdu z elektronicznym systemem wtrysku paliwa

In order to collect data for the application of the proposed methodology will be considered a case of study with a specific malfunction. The case of study will focus on the corrective maintenance of a vehicle with deficient engine performance. The troubleshooting is done according to the malfunction symptom, there are occasions when a malfunction that appears to be generated by the CRS, is actually caused by a different component or system $(\overline{\mathrm{C}} \overline{\mathrm{R}} \overline{\mathrm{S}})$, for instance, engine mechanical parts and fuel system may cause malfunction symptoms identical to symptoms generated by the CRS. Our analysis will focus only on the case where the Damage exposure is related to malfunction of the system components. The diagram presented in Figure 3 show the critical components of the system according to the malfunction under analysis. For computing damage and failure probabilities, will be applied, math based reliability technic FMECA.

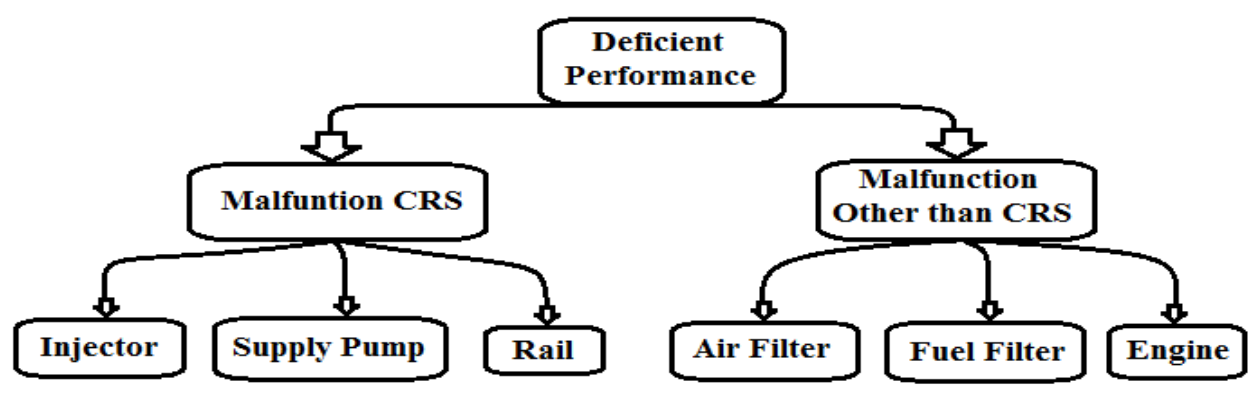

Fig. 3 Critical components of the system

After defining the critical components, is introduced the degree of risk of failure modes for each components. For this, for each component is assigned a probability of occurrence $(\mathrm{O})$, a score for severity of the failure (S), and a score for detectability of failure during the maintenance (D). The values for $\mathrm{O}, \mathrm{S}$ and $\mathrm{D}$ are assigned by engineers. A risk priority number (RPN) is calculated by multiplying $\mathrm{O}, \mathrm{S}$ and $\mathrm{D}$, and is used as a metric to quantify the importance of the component failure [7].

\section{Results}

For this work, critical equipment of the electronic fuel injection system (common rail type) has been identified, considering a certain malfunction. After defining the critical components, will be introduced the degree of risk of failure modes for each component. For this, for each component will be assigned a score for the occurrence $(\mathrm{O})$, severity of the failure $(\mathrm{S})$, and a score for component failure detection (D). A Risk Priority Number (RPN) is calculated as the product of the failure occurrence of an item multiplied by the severity of the component malfunction in the vehicle operation and the difficulty of the damaged component identification ( with, and without use of failure detection equipment).

$$
\mathrm{RPM}=\mathrm{O} * \mathrm{~S} * \mathrm{D}
$$


The linguistic variables such as low, medium and high is used to indicate the, Occurrence, severity and detection. The value of $\mathrm{O}, \mathrm{S}$ and $\mathrm{D}$ range from 1 till 10. Using the Likert Scale, is defined the level of the parameters O, S and D. Once defined each level that marks the limit, it is assigned a factor. The parameter occurrence register the number of time a damage occur in a specific component. The Table 1 and Table 2 shows the assumed values for O, S and D. For simplification, will be represented $\mathrm{S} * \mathrm{D}$.

Table 1. Occurrence level, $1 \leq O \leq 10$

\begin{tabular}{|c|c|c|}
\hline Range of values & Level & Factor \\
\hline $1 \leq \mathrm{O}<4$ & Low & 1 \\
\hline $4<\mathrm{O}<7 ;$ & Medium & 2 \\
\hline $7<\mathrm{O} \leq 10$ & High & 3 \\
\hline
\end{tabular}

Table 2. Severity and detection $\left(S^{*} D\right)$ level, $1 \leq S^{*} D \leq 100$

\begin{tabular}{|c|c|c|}
\hline Range of values & Level & Factor \\
\hline $1 \leq \mathrm{S} * \mathrm{D}<34$ & Low & 1 \\
\hline $34<\mathrm{S} * \mathrm{D}<76$ & Medium & 2 \\
\hline $67<\mathrm{S} * \mathrm{D} \leq 100$ & High & 3 \\
\hline
\end{tabular}

Once defined each level of the parameters $\mathrm{O}$, and $\mathrm{S}^{*} \mathrm{D}$ that marks the limits, is assigned the maintenance strategy. This will depend on the data from the multiplication of $O * S * D$ that allow us to obtain the risk priority number. The Criticality matrix shown in the Table 3, is used to distribute the RPN in three areas: Low, Medium and High.

Table 3. Calculation of the Risk Priority Number (RPN)

\begin{tabular}{|c|c|c|c|c|}
\hline \multirow{2}{*}{} & 3 & Medium (3) & High (6) & High (9) \\
\cline { 2 - 5 } & 2 & Low (2) & Medium (4) & High (6) \\
\cline { 2 - 5 } & 1 & Low (1) & Low (2) & Medium (3) \\
\cline { 2 - 5 } & \multicolumn{4}{|c}{ Impact =(Severity*Detection ) } \\
\cline { 2 - 5 } & \multicolumn{4}{|c}{} \\
\cline { 2 - 5 }
\end{tabular}

The ratings of each of the risk were obtained by multiplying the score of the factors for the occurrence and the impact of the risks $\left(S^{*} D\right)$. The scores of ' 1 ', ' 2 ', ' 3 ' and traffic colour coding were allocated to parameters of 'low', 'medium', and 'high' respectively. The green colour indicates 'low', the yellow colour indicates 'medium' and red colour indicates 'high'. The Table 4 show the calculated RPN for each component. 
Maintenance strategy for vehicle with electronic fuel injection system Strategia obstugiwania pojazdu z elektronicznym systemem wtrysku paliwa

Table 4. RPN assignment for each component according to data collected

\begin{tabular}{|c|c|c|c|c|c|c|}
\hline Component & $\begin{array}{c}\text { Occurrence } \\
\text { (in 20 } \\
\text { vehicles) }\end{array}$ & $\begin{array}{c}\text { Severity } \\
\text { (vehicle } \\
\text { functioning) }\end{array}$ & $\begin{array}{c}\text { Detection } \\
\text { (how } \\
\text { difficult }\end{array}$ & \multicolumn{2}{|c|}{ RPN } \\
\hline Injector & 2 & 9 & 2 & 10 & Low & Medium \\
\hline Supply Pump & 7 & 9 & 2 & 10 & Medium & High \\
\hline Rail & 1 & 9 & 2 & 10 & Low & Medium \\
\hline Air Filter & 4 & 6 & 2 & 10 & Low & Medium \\
\hline Fuel Filter & 4 & 7 & 2 & 10 & Low & Medium \\
\hline Engine & 2 & 10 & 2 & 10 & Low & Medium \\
\hline
\end{tabular}

The values of the parameter D (Detection) is divided in two columns due to its dependence on the availability and correct use of the equipment for the malfunction detection. The first column represents the use of the condition based maintenance (Advanced maintenance), with the use of proper tools, if during the maintenance it is used correctly the necessary equipment's for fault detection, the detection of the malfunction can be considered very easy, evaluated with the grade 2 . The second Colum represents the traditional maintenance, basing in the knowledge and practice, with this method the detection of failure is considered very difficult, evaluated with the grade 10 . This two conditions for the failure detection during the maintenance strategy, has a direct influence in the value of the parameter RPN. The maintenance strategy must be defined considering both condition.

The Table 5, show the maintenance strategy according to the RPN calculation. The Table 6 show the maintenance strategy for each component under analyses considering the two types of maintenance: traditional maintenance and advanced maintenance.

Table 5. Maintenance strategy based on the RPN value.

\begin{tabular}{|c|c|c|c|}
\hline RPM & High & Medium & Low \\
\hline Maintenance & Predictive /preventive & Preventive & Corrective \\
\hline Approach & Monitoring and time & Time and condition & Breakdown \\
\hline
\end{tabular}

Table 6. Maintenance strategy for each component

\begin{tabular}{|c|c|c|}
\hline Component & $\begin{array}{c}\text { Traditional } \\
\text { maintenance approach }\end{array}$ & $\begin{array}{c}\text { Advanced } \\
\text { maintenance approach }\end{array}$ \\
\hline Injector & Corrective & Preventive \\
\hline Supply Pump & Preventive & Predictive \\
\hline Rail & Corrective & Preventive \\
\hline Air Filter & Corrective & Preventive \\
\hline Fuel Filter & Corrective & Preventive \\
\hline Engine & Corrective & Preventive \\
\hline
\end{tabular}




\section{Conclusion}

This works takes in consideration previous studies made by the authors, where was identified the existing problem related to vehicles new technology maintenance as well as operation in developing countries [2]. Others studies has been made focusing in the case of Cape Verde, Praia city where we had a near observation and evaluation by experts working in the city related to vehicle maintenance and operation, who has a real knowledge of the problem $[1,2,4]$. Previous studies also has shown that the study of the local needs and conditions is very important before the introduction of the new vehicles technologies, this ca ensure an reliable vehicle operation. The maintenance is the key strategy to ensure a proper vehicle operation.

With the elaboration of this work was possible to visualize that the maintenance strategy for each component depends strongly on the availability of equipment for the diagnosis (fault detection). As this work focus on the maintenance of vehicle in developing countries, where majority of the maintenance workshop does not have access to equipment's and/or the operator does not have the acquired knowledge for the efficient use and operation of the equipment's, this work present an alternative for the maintenance strategy in order to increase the reliability of vehicles operation.

As future work, would be important to introduce others parameters that influence the maintenance and vehicle operation as cost, environment, human aspect and vehicle operation. Another useful analyses would be, to analyses the data in a probabilistic interpretation by defining the Occurrence proportional to the probability of observing a failure in the component when a damage is observe and the Severity as the conditional probability that the vehicle fails given that a component fails. With this is possible to calculate for every component the probability that component fails when observing a failure of the vehicle, and to calculate the probability that the common rail system (CRS) is damaged when it happens that the vehicle fails. All this calculation can be done by implementing a code that calculate the conditional probability mentioned.

\section{Acknowledgment}

The work has been financially supported by the Polish Ministry of Science and Higher Education.

\section{References}

[1] Monteiro T. C., Szpytko J.: Selected problems of control the urban transport system, Cape Verde case study/ Problemy sterowania systemem transportu miejskiego na przykładzie Wyspy Zielonego Przylądka. Logistyka, 4, 49774983, 2015 (ISSN 1231-5478).

[2] Monteiro T.C., Szpytko J.: Vehicles Emerging Technologies from Maintenance Perspective. 3rd IFAC AMEST Workshop on Maintenance Technologies for Performance Enhancement, Biarritz, France, 19-21 October 2016, Preprints, Edited by: Christos Emmanouilidis, Benoît Iung, Marco Macchi and François Pérès, IFAC, IFAC-PapersOnLine, 49 (28), 67-72, 2016 (ISSN 2405-8963, 2016). 
Maintenance strategy for vehicle with electronic fuel injection system Strategia obstugiwania pojazdu z elektronicznym systemem wtrysku paliwa

[3] Du X., Chen W.: Sequential Optimization and Reliability Assessment for Probabilistic Design. ASME Journal of Mechanical Design, 126 (2), 225-233, 2004.

[4] Monteiro T.C., Szpytko J.: Electric fuel injection engine reliability problems in developing countries, Cape Verde case study. Journal of KONES: Powertrain and Transport, 23 (4), 351-358, 2016 (ISSN 1231- 4005).

[5] Denso Corporation: Service manual: Common Rail System (CRS). Diesel Injection Pump, 2007.

[6] Fedele L.: Methodologies and technics for advanced maintenance. Springer, London, 2011.

[7] Smith R., Keith R. K.: Rules of thumb for maintenance and reliability engineers. Oxford, Butterworth-Heinemann, 2008.

[8] Xiao N., Huang H-Z., Li Y., He L., Jin T.: Multiple failure modes analysis and weighted risk priority number evaluation in FMEA. Engineering Failure Analysis, 18 (4), 1162-1170, 2011.

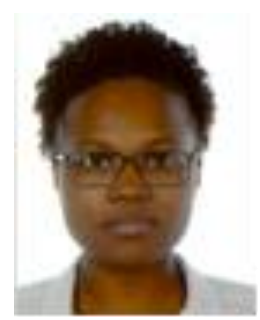

Carla Mericia Monteiro Tavares, M.Sc. in M.Eng, FCT-UNL New University of Lisbon, Faculty of Science and Technology, 2013. Research team leader in SOGILUB (integrated management company of used lubricating oil) in cooperation with FCT-UNL, Portugal (10/2012 - 06/2013). General manager of business services at maintenance workshop in Filipe Auto Luis e Fernanda Ltd., Cape Verde. PhD student in AGH UST, Krakow from 2015 to present. Author of 4 publications, touching to vehicles maintenance and operation and emerging technologies. 7 presentations during seminars.

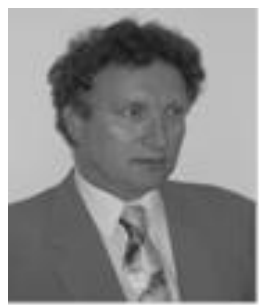

Prof. Dr hab. C.Eng. Janusz Szpytko, AGH University of Science and Technology. Specialist in designing and exploitation of transport systems and devices, automatics, safety and reliability, monitoring and diagnostics, decision making systems, telematics. Author or co-author of more than 500 publications. Member of: STST KTPAN, TC IFAC, SEFI, ISPE, PTD, PTB, PSRA, ISA, SITPH and others. Visiting professor at the universities in: UK, France, Canada, Italy, Greece, Organizer and member of several scientific and programme committees of international and national conferences and symposiums. 